\title{
Toxin profile change in vegetative cells and pellicle cysts of Alexandrium fundyense after gut passage in the eastern oyster Crassostrea virginica
}

\author{
Barry C. Smith ${ }^{1, *}$, Agneta Persson ${ }^{1,3}$, Erik Selander ${ }^{2,4}$, Gary H. Wikfors ${ }^{1}$, \\ Jennifer Alix ${ }^{1}$ \\ ${ }^{1}$ Milford Laboratory, Northeast Fisheries Science Center, National Marine Fisheries Service, \\ NOAA, Milford, Connecticut 06460, USA \\ ${ }^{2}$ Sven Lovén Center for Marine Research, Göteborg University, Kristineberg 566, 45034 Fiskebäckskil, Sweden \\ ${ }^{3}$ Present address: Department of Marine Ecology, Göteborg University, Box 461, 40530 Göteborg, Sweden \\ ${ }^{4}$ Present address: DTU Aqua, Technical University of Denmark, Charlottenlund Castle, Jaegersborg Alle 1, \\ 2920 Charlottenlund, Denmark
}

\begin{abstract}
Vegetative cells and pellicle cysts of the toxic dinoflagellate Alexandrium fundyense Balech were fed to the eastern oyster Crassostrea virginica Gmelin under controlled conditions. Paralytic shellfish toxins (PSTs) were measured in vegetative cells and pellicle cysts prior to feeding and directly after passage through the oyster alimentary canal and defecation as intact cells. Oysters fed with vegetative cells and those fed with pellicle cysts accumulated toxins. One experimental treatment tested for direct uptake of toxins from the water (oysters and $A$. fundyense cells were separated by a screen); PSTs were not accumulated from the water by the oysters. There were no significant changes in total, per-cell toxicity after passage through the oyster alimentary canal, suggesting limited transfer of toxins from intact cells to the oysters. However, there were statistically significant changes in the toxin composition of cells following gut passage. Vegetative cells and pellicle cysts from feces had increased amounts of saxitoxin (STX) and decreased amounts of gonyautoxin 4 (GTX4) per cell, compared to amounts prior to gut passage. Following gut passage, pellicle cysts showed better survival in the feces than vegetative cells, which is consistent with the view of pelliclecyst formation as a successful survival strategy against adverse conditions.
\end{abstract}

KEY WORDS: Alexandrium fundyense $\cdot$ Crassostrea virginica $\cdot$ Dinoflagellate $\cdot$ Toxin $\cdot$ PST $\cdot$ Pellicle cyst

\section{INTRODUCTION}

The dinoflagellate Alexandrium fundyense is one of several microalgae that produce paralytic shellfish toxins (PSTs), i.e. saxitoxin and its derivatives (>50 compounds with different toxicities). PSTs are perhydropurine alkaloids that share a tricyclic carbon backbone but differ in their functional groups at 4 positions (Schantz 1960, Wiese et al. 2010). The transfer and accumulation of PSTs into commercially harvested shellfish soft tissues is a global human-health issue (Bricelj \& Shumway 1998, Anderson et al. 2002, Wang
2008) that is managed by toxin monitoring programs and harvesting bans when toxin limits are exceeded. When Alexandrium spp. vegetative cells are filtered by oysters and other mollusks, some cells can pass through the bivalve digestive system alive. The proportion of cells that survive gut passage is variable, depending upon such factors as concentration, species, and health status of the shellfish, but it can be considerable (Laabir \& Gentien 1999 and references therein, Garcés et al. 2002, Persson et al. 2006, Hégaret et al. $2007,2008)$. At some point during the capture and ingestion process by shellfish, Alexandrium spp. cells 
cast off the thecae and flagella, and enter a protected stage known as the 'pellicle cyst' (also termed 'temporary' or 'ecdysal'). Dinoflagellates form pellicle cysts quickly when they encounter unfavorable conditions, e.g. shaking of culture flasks, transfer of cells into new nutrient media, or change in temperature. Pellicle cyst transformation can protect the dinoflagellates from exposure to harmful substances or conditions (Garcés 2001, Tillmann et al. 2007) as well as from parasite infection (Toth et al. 2004). When the environment again becomes favorable for vegetative growth, the cells form new thecae and flagella, swim again, and continue to grow by binary fission. These cells can swim again in $<24 \mathrm{~h}$ if put into a growth medium (unpubl. obs., this experiment).

It is usually assumed that PSTs remain within dinoflagellate cells until they are digested, but it is difficult to measure PSTs that may be released by cells into salt water because salt interferes with the analysis. It is possible to use activated charcoal columns to collect the toxins, as has been done in some studies with bivalves (Sekiguchi et al. 2001, Suzuki et al. 2003, Asakawa et al. 2006). Lefebvre et al. (2008) measured the extracellular toxin levels in both field samples and laboratory cultures by receptor binding assay (RBA) and enzyme-linked immunosorbent assay (ELISA). This study showed that extracellular PSTs were present during blooms of Alexandrium spp., and in culture media. In many experiments with PST-producing dinoflagellates, data indicate that PSTs were released into the medium (e.g. Flynn et al. 1996, Wang et al. 2002, Kim et al. 2005). For dinoflagellates that produce hydrophobic toxins associated with DSP (diarrhoeic shellfish poisoning), toxins dissolved in the water are measured with the so-called 'SPATT (solid phase adsorption toxin tracking) bags' filled with a polymeric resin that adsorbs hydrophobic compounds (MacKenzie et al. 2004, Fux et al. 2008, 2009). During DSP-producing blooms, significant amounts of DSP toxins are dissolved in the seawater (MacKenzie et al. 2004). In the case of freshwater cyanobacteria that produce PSTs, the toxins are released into the water (Filho Ada et al. 2008, Kayal et al. 2008), and this can be interpreted as a chemical defense strategy. Okadaic acid, which is produced by the dinoflagellate Prorocentrum lima, is also released into the extracellular medium (Rausch de Traubenberg \& Morlaix 1995). The ability of oysters to sense the presence of toxic algae and quickly cease feeding (e.g. Bardouil et al. 1993, Wildish et al. 1998) suggests that PSTs could be expelled as a defense or an allelopathic substance by Alexandrium spp. in the marine environment. Hwang et al. (2007) showed that PSTs, specifically gonyautoxins (GTX) 1 to 4, attracted snails that acquire this toxin through feeding and use it as a defense strategy.
It is theoretically possible for toxic dinoflagellates to release toxins during gut passage in oysters without being digested. If so, this could cause toxicity in oysters without eliminating ingested dinoflagellate cells. Egested living cells could continue to divide and form new toxins again.

This study explored cellular PSTs, both in terms of total toxicity per cell and toxin composition, in Alexandrium fundyense cells before and immediately after oyster feeding on intact cells and pellicle cysts, and also investigated the possibility of direct uptake of PSTs from the water.

\section{MATERIALS AND METHODS}

\section{Cultures and culturing conditions}

We used Alexandrium fundyense strain BF-2 (length: $32.2 \pm 2.3 \mu \mathrm{m}$ SE, width: $30.7 \pm 2.6 \mu \mathrm{m}$ ) from the NOAA/ NMFS Milford Microalgal Culture Collection (isolated from the Gulf of Maine). This strain was cultured in $f / 2$ medium with no silicate added at $16^{\circ} \mathrm{C}, 14 \mathrm{~h}$ light:10 h dark cycle, and $100 \mu \mathrm{E} \mathrm{m}{ }^{-2} \mathrm{~s}^{-1}$ photosynthetically active radiation (PAR). Cells in the early stationary phase were used for the oyster-exposure experiment.

Alexandrium fundyense pellicle cysts were produced by vigorous shaking of a portion of the same culture as used for vegetative-cell treatments. The subculture was vortexed (Vortex-Genie 2, Scientific Industries) for 2 min and then rinsed on a $20 \mu \mathrm{m}$ screen with filtered seawater; thereafter, the volume was reconstituted with filtered seawater. The cells were confirmed to be intact immobile pellicle cysts by light microscopy. Pellicle cysts are also commonly called 'temporary' or 'ecdysal' cysts, and here we use 'temp' for the pellicle cysts in tables and figures since the pellicle cyst is a short temporary state for this species.

\section{Oysters}

Oysters Crassostrea virginica from Long Island Sound (mean shell length: $83 \pm 5 \mathrm{~mm}$ ) were obtained from Fishers Island Shellfish Farm, Fishers Island, New York. The oysters were kept in the laboratory for $\sim 1 \mathrm{wk}$ in running, unfiltered seawater until experimental use. Temperature was increased by $2^{\circ} \mathrm{C} \mathrm{d}^{-1}$ from 12 to $18^{\circ} \mathrm{C}$. Before the experiment, oysters were brushed, washed and placed in $0.1 \mu \mathrm{m}$ filtered seawater for $3 \mathrm{~d}$ in the room where the experiment was later to be performed. Oysters were fed with one ration of Tetraselmis striata (Plat-P) immediately after transfer, but were starved thereafter until the start of the experiment. Water was changed daily. 
Table 1. Experimental treatments

\begin{tabular}{|lcc|}
\hline Treatment & Cells & Live oyster \\
\hline Alex & Vegetative cells & Yes \\
Temp & Pellicle (= temporary) cysts & Yes \\
Screen & $\begin{array}{l}\text { Vegetative cells, separated } \\
\text { from the oyster by a screen } \\
\text { Control }\end{array}$ & Yes \\
& Vegetative cells & No \\
\hline
\end{tabular}

\section{Experimental design}

Experimental treatments (Table 1) were established in 11 polypropylene beakers. Each treatment had 5 replicates, and each replicate was 1 beaker that contained 1 oyster (or empty oyster shell, to account for physical trapping of Alexandrium cells by the shell itself), and 11 of $0.1 \mu \mathrm{m}$ filtered seawater. Unfed oysters were maintained in filtered seawater as a control for oyster soft-tissue toxin content.

The experiment was conducted in a constant-temperature room at $18^{\circ} \mathrm{C}$ with $35 \mu \mathrm{E} \mathrm{m}{ }^{-2} \mathrm{~s}^{-1}$ PAR artificial illumination (room lights) from above (as measured inside the beakers before the experiment). A single, high-concentration dose of cells was used to optimize the number of undigested cells in the feces, because these were the study material. A short total time for the experiment was necessary because aeration or stirring could not be used (the feces needed to be identifiable and intact for picking). A cell number that was high enough to yield a sufficient quantity of intact cells in feces samples for toxin measurements was needed, while avoiding the risk of a valve-closure response at high cell numbers. A balance between these needs was achieved through experience from earlier experiments with oysters and Alexandrium fundyense (Persson et al. 2006, A. Persson et al. unpubl. data).

For vegetative-cell treatments, 5 samples were collected at the start of the experiment, and 4 were collected for the pellicle-cyst treatment, for toxin analysis. For the enumeration of cells, 5 samples were taken from each culture before the start of the experiment. Then, the experiment was started by the addition of $16 \mathrm{ml}$ of cultured vegetative cells or pellicle cysts to each beaker. This procedure yielded 670000 cells beaker $^{-1}$ for vegetative cells and 595000 cells beaker ${ }^{-1}$ for pellicle cysts.

The oysters were allowed to feed for $23 \mathrm{~h}$. Oysters in the treatment wherein cells and oysters were separated by screens were given $5 \mathrm{ml}$ of a Nannochloropsis sp. (UTEX2341) culture $\left(1 \times 10^{7}\right.$ cells ml $\left.^{-1}\right)$ after $20 \mathrm{~h}$ to determine if the oysters were actively filtering. Nannochloropsis sp. are small $(2-4 \mu \mathrm{m})$ cells that have a bright green color. They are not digested by oysters, pass quickly through the alimentary canal, and are visible in feces. Appearance of bright green feces is confirmation that oysters are actively filtering.

\section{Termination of the experiment}

Feces produced in each beaker were carefully picked with a pipette and saved in a beaker in a refrigerator $\left(4^{\circ} \mathrm{C}\right)$. The next day, they were pooled with the rest of the feces from the same oyster (see below), and rinsed on a $20 \mu \mathrm{m}$ screen with filtered seawater to remove broken cells and debris, leaving only intact pellicle cysts. The sample was rinsed into a $100 \mathrm{ml}$ volumetric flask with filtered seawater and brought to volume. Pseudofeces were not found (and not expected at this cell density given our earlier experience from studies using the same algal and oyster species; Persson et al. 2006, A. Persson et al. unpubl.).

Oysters in the treatment wherein cells and oysters were separated by screens were carefully removed from the water before filtering it to ensure that oysters were not in direct contact with any cells at any time. The beaker water (without feces) was rinsed with filtered seawater onto a $20 \mu \mathrm{m}$ sieve, and the container and the live oyster, or empty oyster shell, were also rinsed with filtered seawater onto the sieve. Then the material on the sieve was transferred to a 100 or $200 \mathrm{ml}$ volumetric flask, and brought to volume. Samples were taken for cell counts and for toxin measurement according to the description below. Samples for cell counts were taken from the volumetric flasks ( 3 to $4 \mathrm{ml}$ ) and preserved with iodine crystals. Cells were counted in a Sedgewick-Rafter counting cell with a light microscope.

Samples for toxin measurements were gently filtered onto $25 \mathrm{~mm}$ GF/F. The filters were put in Eppendorf vials and directly frozen with lids open to dry the filters. Then $1 \mathrm{ml}$ of $0.05 \mathrm{M}$ acetic acid was added to each Eppendorf vial. The sample was frozen, thawed, and shaken $4 \times$. After the last freezing, the samples were thawed and aspirated with a $1 \mathrm{ml}$ syringe. Special filters with very little dead volume had been made; a $1 \mathrm{ml}$ pipette-tip cut off to fit on the syringe had a small piece of GF/F inserted inside the tip. The sample was pressed with the syringe through the filter in the tip into a HPLC vial which was then crimp sealed. Samples from the control and screen treatments were divided into two; one part was extracted with acetic acid as described above, and the other was extracted with $0.1 \mathrm{~N} \mathrm{HCl}$. This was done to calculate the concentrations of $\mathrm{C}$ toxins in the sample (see below).

At the end of the experiment, after oysters were rinsed, they were placed in new, clean beakers with $0.5 \mathrm{l}$ of filtered seawater. To each beaker, $5 \mathrm{ml}$ of $\mathrm{Nan}$ nochloropsis sp. culture (as described above) were 
added to monitor progress through the oyster digestive systems. The oysters were left in the beakers (in the same culturing room as above) overnight. All material in the beakers was rinsed and sieved thoroughly with filtered seawater, as above, to remove Nannochloropsis cells and fecal components. Feces samples were saved for toxicity measurements and Alexandrium cell counts.

Oysters were kept dry in a refrigerator $\left(4^{\circ} \mathrm{C}\right)$ overnight, and they were then 'shucked' to extract soft tissues, which were then rinsed in running, cold tap water. The soft-tissue mass was weighed, homogenized with a tissue homogenizer and divided into two. One part was extracted with boiling $0.1 \mathrm{~N} \mathrm{HCl}$ for 5 min according to the protocol of Oshima (1995); the other part was extracted with $0.05 \mathrm{M}$ acetic acid without boiling. The extracted soft-tissue samples were frozen $\left(-80^{\circ} \mathrm{C}\right)$. Oyster tissue samples were transferred into $15 \mathrm{ml}$ centrifuge tubes and thawed, and the original sample volume restored with distilled water. Samples were vortexed, then centrifuged at $1000 \times g$, and the supernatant was filtered into HPLC vials as described above.

Toxin analysis. Samples for toxin analysis were shipped frozen to the Department of Marine Ecology at the Sven Lovén Center for Marine Research, Tjärnö, Sweden, and stored at $-20^{\circ} \mathrm{C}$ until sample analysis.

Paralytic shellfish toxins were analyzed using HPLC with fluorescence detection (HPLC-FD) according to Asp et al. (2004). HPLC analyses were carried out on a Hitachi-7000 system equipped with a RP8 Column (Genesis C8, Vymac $4 \mu \mathrm{m}, 150 \mathrm{~mm}$, inner diameter = $3 \mathrm{~mm}$ ). PST standards (saxitoxin, decarbamoylsaxitoxin, neosaxitoxin, and gonyautoxin GTX1 to 4) were purchased from NRC-CNRC, Halifax, Nova Scotia, Canada. The samples contained both $\mathrm{N}$-sulfocarbamoyl toxins (C toxins) and carbamates. As $\mathrm{C}$ toxins are not retained in the HPLC method, a hydrolyzed sample $(0.1 \mathrm{~N} \mathrm{HCl})$ was analyzed to calculate the concentration of C-toxins based on the increase in corresponding carbamates, compared to non-hydrolyzed samples extracted with $0.05 \mathrm{M}$ acetic acid. GTX1 to 4 were resolved and analyzed using isocratic elution with Eluent A: $2 \mathrm{mM}$ sodiumheptanesulfonate in 10 $\mathrm{mM}$ ammonium phosphate buffer (pH 7.1). Saxitoxin, neosaxitoxin, and dc-saxitoxin were analyzed using isocratic elution with Eluent B: $2 \mathrm{mM}$ sodiumheptanesulfonate in $30 \mathrm{mM}$ ammonium phosphate buffer $(\mathrm{pH}$ 7.1): acetonitrile (96:4). After the separation, toxins were oxidized with $7 \mathrm{mM}$ periodic acid in $50 \mathrm{mM}$ sodium phosphate buffer $\left(\mathrm{pH} 9.0,0.2 \mathrm{ml} \mathrm{min}{ }^{-1}\right)$ in a PEEK capillary $\left(10 \mathrm{~m}, 80^{\circ} \mathrm{C}\right)$. The oxidation was terminated with $0.5 \mathrm{M}$ acetic acid $\left(0.2 \mathrm{ml} \mathrm{min}^{-1}\right)$ before fluorescence detection at $\lambda_{\mathrm{ex}}=330 \mathrm{~nm}$, and $\lambda_{\mathrm{em}}=390 \mathrm{~nm}$.
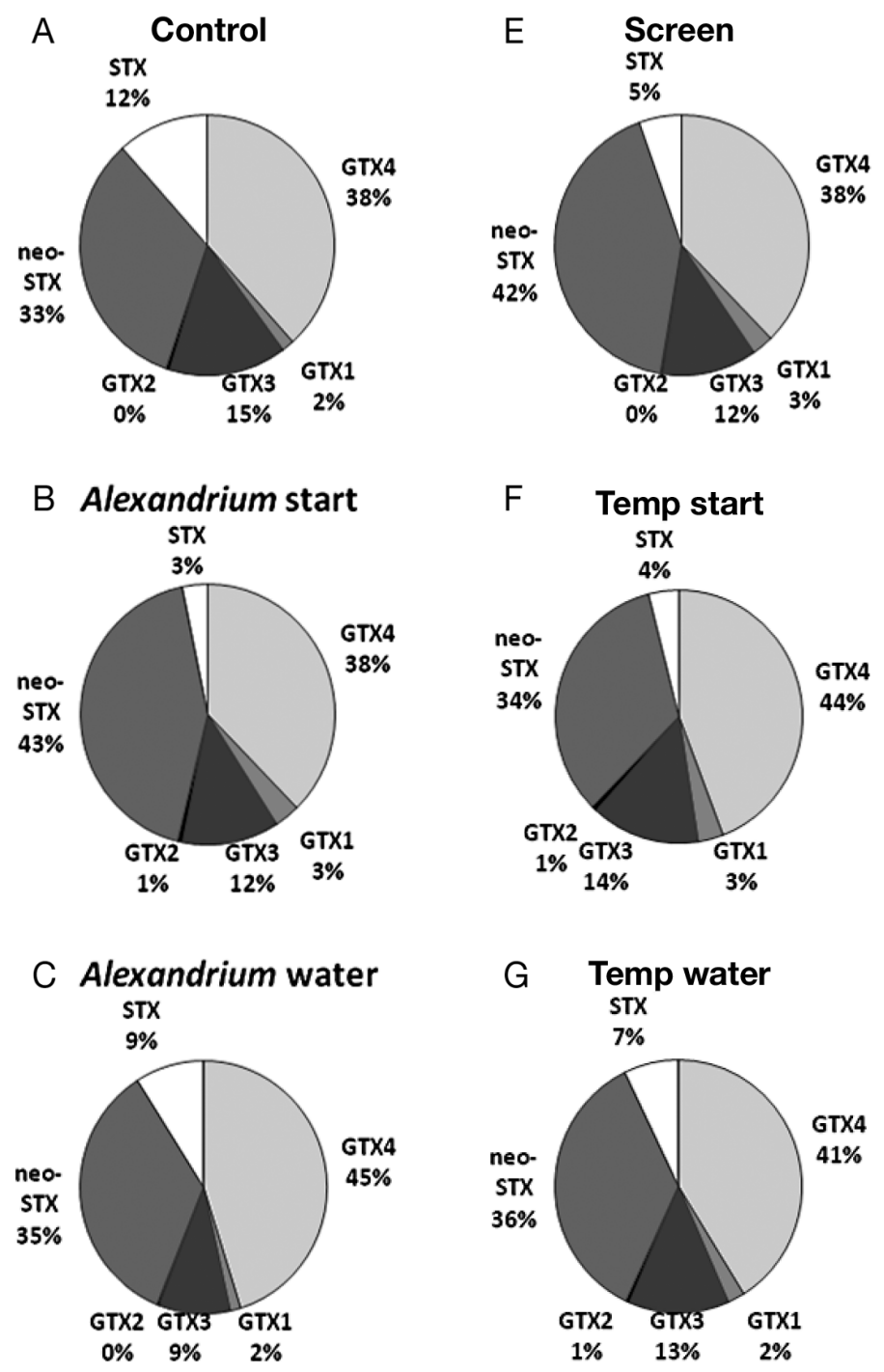

\section{Alexandrium feces}

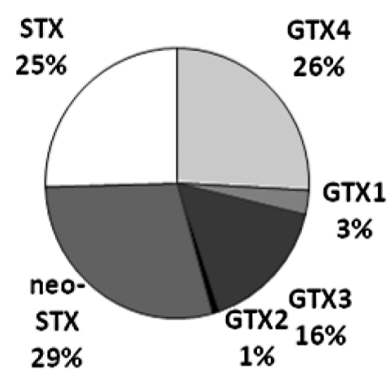

\section{H Temp feces}

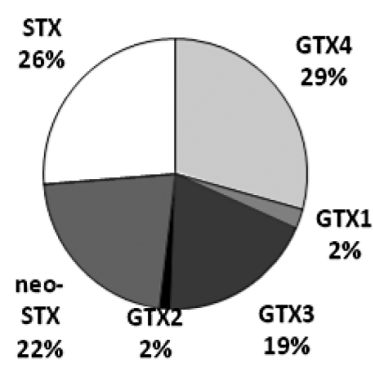

Fig. 1. Alexandrium fundyense. Proportional changes in toxin profile before and after oyster gut passage. $\mathrm{C}$ toxins are not included since they were measured only in the control and screen treatments. (A) No-oyster controls; (E) screen treatments: cells were separated from the oysters by a $20 \mu \mathrm{m}$ screen; (B, F) start: vegetative cells and pellicle cysts at the beginning of the experiment; $(\mathrm{C}, \mathrm{D})$ Alexandrium: vegetative cell treatments; $(G, H)$ temp: pellicle (temporary) cyst treatments. Water: cells not in feces at the end of the experiment; feces: cysts found in oyster feces; GTX: gonyautoxins, STX: saxitoxin 


\section{RESULTS}

Oysters actively filtered both vegetative cells and pellicle cysts of Alexandrium fundyense from suspension, producing feces containing mainly pellicle cysts. There were significant changes in toxin composition during transport through the oyster digestive system (Fig. 1); intact cells from feces samples had a significantly different PST composition compared to all other samples. The principal toxin in uningested cells (start, control, water and screen) was GTX4, followed by neosaxitoxin (neoSTX) and GTX3 (Figs. 1 \& 2). C toxins were determined for control and screen treatments, and the principal C toxin was C2 (see below). The levels of saxitoxin (STX) were significantly higher $(\mathrm{p}<$ 0.01 ), and the GTX4 toxin level was significantly lower $(p<0.04)$ in feces samples; the change was the same for cells that were initially vegetative cells as for those that were initially pellicle cysts.

The measurements of toxicity in oyster soft tissues were done without internal toxin standards and additional cleaning steps, and are therefore only qualitative. Impurities in these samples resulted in difficulties in identification and quantification of PSTs. The presence of GTX4 and neoSTX in soft tissues from oysters fed with vegetative Alexandrium fundyense, and oysters fed with pellicle cysts was evident, whereas no PSTs accumulated in the oyster soft tissues in the screen treatment. Toxin levels were $\sim 0.03 \mu \mathrm{mol}$ GTX4 $\mathrm{g}^{-1}$ and $0.15 \mu \mathrm{mol}$ neoSTX $\mathrm{g}^{-1}$ soft tissue for oysters feeding on vegetative cells or pellicle cysts. All A. fundyense cells in the pellicle-cyst treatment (temp)

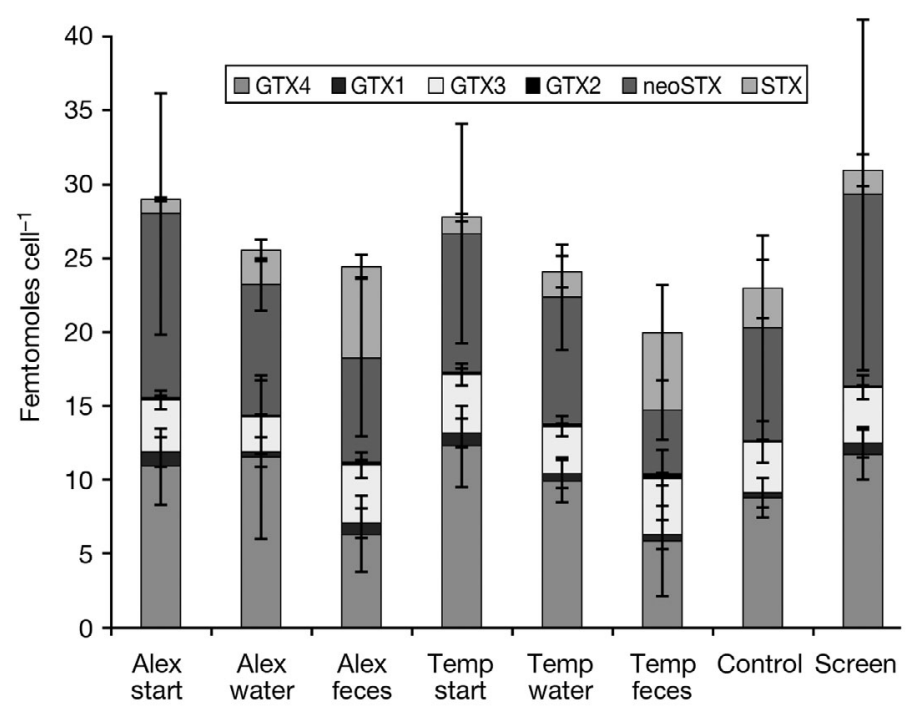

Fig. 2. Alexandrium fundyense. Toxicity in the different treatments. $\mathrm{C}$ toxins are not included since they were measured only in the control and screen treatments. Error bars: SD. (See Fig. 1 for treatment explanations)

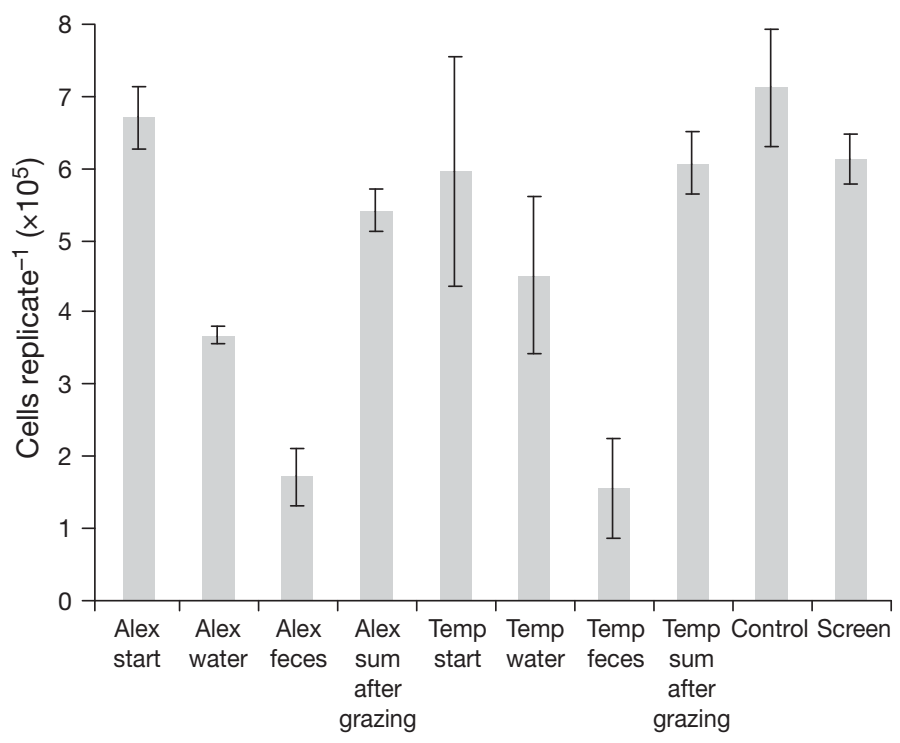

Fig. 3. Alexandrium fundyense. Cell numbers (total number of cells per 11 beaker). Bars: average number of cells in beakers in each treatment. Error bars: SD. (See Fig. 1 for treatment explanations)

were immobile pellicle cysts at the start of the experiment. However, there were numerous swimming cells near the upper end of the beakers, toward the brighter side, at the end of the experiment (Fig. 3). The feces contained many empty thecae and membranes/ pellicles that had surrounded the pellicle cysts; these appeared to have germinated, i.e. they were not digested or destroyed, but left by cells returning to the vegetative stage (Fig. 4). This was especially apparent in the pellicle-cyst treatment. In feces from the vegetative-cell treatment, there were some clumps of cells

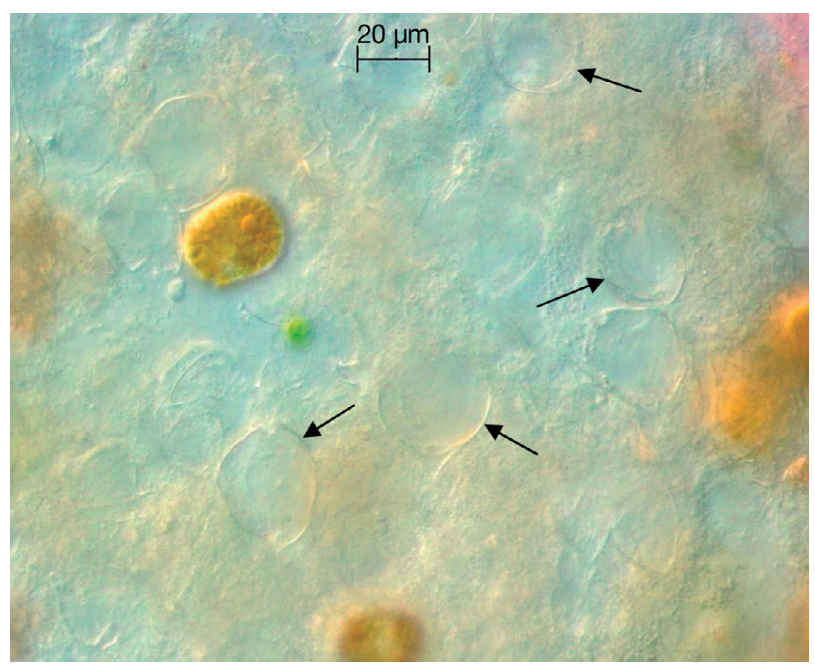

Fig. 4. Oyster feces from pellicle cyst treatment, with empty thecae and pellicle membranes (arrows) 
and some cells that did not appear to be alive, in addition to the living pellicle cysts that were the main component in the feces samples (Fig. 5). Toxin analyses were performed on rinsed samples containing intact cells and no broken cells or half-digested material. Compared to the numbers at the start, the sums of $A$. fundyense cells present after filter-feeding (feces + water) were significantly lower for the vegetative cell treatment, but not for the pellicle cyst treatment. The mean digestion of cells was $19 \%$ in the vegetative cell treatment $(p=0.004)$, but no digestion could be shown by statistical analysis of cell numbers in the pellicle cyst treatment ( $\mathrm{p}=0.88$ ) (Fig. 3), although the accumulation of toxins in oyster soft tissues indicates that digestion took place. Vegetative cells in the water were swimming along the upper edge of the beaker near the brightest side. In beakers containing screens, A. fundyense cells swam up along the screen, or were caught by surface tension near the screen.

The results from the feces are based on the oysters that defecated sufficient material for analysis: 3 replicates from the vegetative (Alex) treatment and 4 from the pellicle cyst (temp) treatment. It was difficult to ascertain if the oysters in the screen treatment were actively filtering, as they could not produce biodeposits without food. The valves appeared to be closed, so Nannochloropsis sp. culture was added $3 \mathrm{~h}$ before the end of the experiment. After this, 2 oysters defecated, but only very little. All oysters in the experiment filtered and defecated after the experiment, when placed

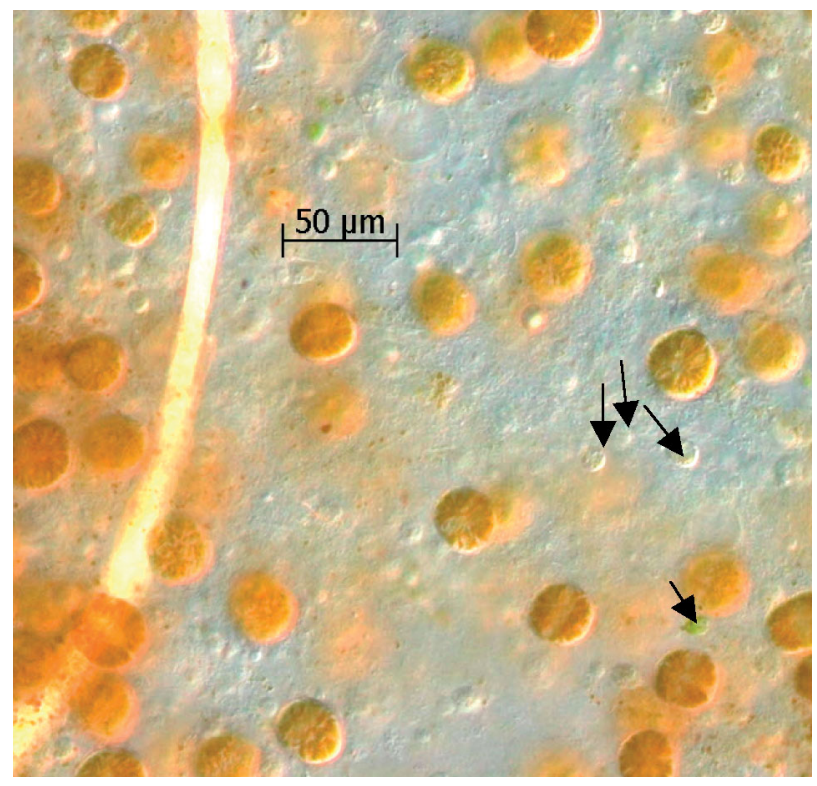

Fig. 5. Oyster feces from the Alexandrium (vegetative cell) treatment before rinsing. Intact but immobile living cells of Alexandrium (pellicle cysts) can be seen, as well as small Nannochloropsis cells (arrows) and debris in clean containers and fed with Nannochloropsis sp., hence they were all assumed to be in a fully healthy state.

Screen treatments and no-oyster controls were extracted both with $\mathrm{HCl}$ and acetic acid, which provided information about the $\mathrm{C}$ toxins through calculation of the increase in corresponding carbamates in hydrolyzed compared to non-hydrolyzed samples. Alexandrium fundyense cells in the control treatments contained (mean $\pm \mathrm{SD}$ ) $12.0 \pm 4.2 \mathrm{fmol} \mathrm{C} 2$ toxin cell ${ }^{-1}$, and cells in the screen treatment contained on average $14.7 \pm 6.2 \mathrm{fmol} \mathrm{C} 2$ toxin cell ${ }^{-1}$. C1 was present in trace amounts, but $\mathrm{C} 3$ and $\mathrm{C} 4$ were not detected.

\section{DISCUSSION}

The toxin content per Alexandrium fundyense cell did not decrease significantly during passage through the oyster digestive system, but there were significant changes in toxin composition. Thus, A. fundyense cells that survived gut passage did not release much toxin prior to being egested. The change in toxin composition in A. fundyense cells during gut passage cannot be attributed to digestion because total toxicity did not decrease, and the cells were still alive. Our results show that toxin transformations can take place within living dinoflagellate cells before digestion, thus before assimilation of toxins into bivalve tissues. There was significantly less GTX4 and significantly more STX in A. fundyense cells recovered from feces than in cells before gut passage, which is consistent with the descriptions of toxin transformations (from source Alexandrium cells to bivalve soft tissues) reported in the literature (e.g. Bricelj \& Shumway 1998, Li 2004, Jaime et al. 2007); these reports concluded that STX can be formed directly from neosaxitoxin and, through other intermediate forms, also from GTX4 and C toxins. The BF-2 strain of $A$. fundyense used in the present study contained $\mathrm{C} 2$ toxins which, with GTX3 as an intermediate, can also form STX. It should be noted that the toxin transformations seen here are from less toxic to more toxic forms, which has implications for the interpretation of the biological relevance of these toxin transformations. The transformation to more toxic forms has also been shown in scallops (Cembella et al. 1994) and in surf clams (Shumway et al. 1994). A passive change in the internal $\mathrm{pH}$ in living cells resulting from the lower $\mathrm{pH}$ of the surrounding digestive fluids is a possible explanation, and the subject will be studied further. Discovery of these toxin transformations within $A$. fundyense cells experiencing the extraordinarily stressful conditions within the digestive system of an oyster also adds to the evidence that Alexandrium spp. toxin 
composition is not an exact 'fingerprint' for a species, but is rather variable depending on environmental factors affecting the cell. There are many reports of changes in toxin profile in different conditions or environments (Ravn et al. 1995, Ciminiello et al. 2000, Hamasaki et al. 2001, Parker et al. 2002, Teegarden et al. 2003, Etheridge et al. 2004, Kim et al. 2005), although other papers argue that the toxin profile can be considered as a fingerprint (e.g. MacKenzie et al. 1996, Ichimi et al. 2001). Information about the biological significance of the different toxin forms is incomplete, but it cannot be ruled out that changes to more toxic forms that occur in living cells in a threatening situation might have a biological cause. The information in the literature on what affects toxicity is very diverse: temperature, salinity, light, $\mathrm{N}$ and $\mathrm{P}$ limitation (e.g. Anderson et al. 1990), life stage (Cembella et al. 1990), division cycle (Taroncher-Oldenburg et al. 1999) and shock (Ravn et al. 1995) can affect Alexandrium spp. toxicity levels and/or profiles. The presence of grazers induces a higher toxin production in $A$. minutum (Selander et al. 2006, Bergkvist et al. 2008).

The oyster soft tissues in our experiment contained GTX4 and neosaxitoxin, which are the 2 dominating forms of toxin in the dinoflagellates, but not STX. Transformation of toxin forms occurs both by enzymatic processes and by spontaneous chemical reactions with pH change (Bricelj \& Shumway 1998, Li 2004, Jaime et al. 2007). These transformations probably occur as part of digestive or metabolic processes. Jaime et al. (2007) showed toxin transformation in vitro with toxin extracts from Alexandrium fundyense and different shellfish tissues. Asakawa et al. (1995) showed different toxin profiles in $A$. tamarense and the bivalves that ingested them. Cembella et al. (1993) suggested that toxin conversions might be particularly significant during the early stages of digestion when dinoflagellate cells are still intact and metabolically active. It is clear that changes in toxin structure occur during digestion, and also within cells that survive gut passage. It is possible that some of the swimming cells in the beakers might have passed the oysters and returned to the mobile phase, considering that the feces contained empty thecae and pellicle membranes (that would likely be destroyed if they were empty during gut passage; Fig. 4). It is unknown if these cells would maintain the changed toxin profile for any length of time, as we do not know the proportion of these cells among the swimming cells. Laabir et al. (2007) showed changed toxin profiles in cultures of Alexandrium catanella and A. minutum that were established from pellicle cysts collected from molluscan feces.

The digested cells caused accumulation of toxins in the oyster soft tissues, from both vegetative cells and pellicle cysts. No direct uptake of PSTs from the water was shown to occur. As oysters seemed to close their shells, thus restricting exposure of soft tissues to water in the beakers containing Alexandrium fundyense cells separated from the oysters by a screen, we cannot exclude the possibility that direct PST uptake from the water can occur in nature or in other experiments. Oysters (Crassostrea spp.) are more sensitive to neurotoxins than many other bivalves (Twarog et al. 1972, Shumway et al. 1990). In most studies, the PST content of the medium was not measured. In a few studies with bivalves, a column with activated charcoal was used to adsorb dissolved PSTs for subsequent elution and analysis (Sekiguchi et al. 2001, Suzuki et al. 2003, Asakawa et al. 2006). A recent study by Lefebvre et al. (2008) using a receptor-binding assay (RBA) and an enzyme-linked immunosorbent assay (ELISA) found extracellular PSTs in both field samples and laboratory cultures. Activated charcoal is used to remove saxitoxin in freshwater treatments (Falconer et al. 1989, Orr et al. 2004), but this treatment is not $100 \%$ effective (Newcombe \& Nicholson 2002, 2004, Orr et al. 2004). Thus, although seldom measured, extracellular PSTs are present both in laboratory cultures in experiments, and in the field.

Fewer pellicle cysts than vegetative cells were digested; this is consistent with the view that the pellicle cyst is a protective stage. Pellicle cysts cannot be penetrated by the nuclear stain SybrGreen, unlike vegetative cells (pers. obs.). It appears that when dinoflagellate cells form pellicle cysts, they quickly close many ports of communication or intake of substances, and this protects them from digestive fluids, albeit incompletely.

\section{CONCLUSIONS}

PSTs were not released from cells of Alexandrium fundyense that survived passage through the oyster (Crassostrea virginica) digestive system. However, there was a significant change in toxin profile from less toxic to more toxic forms within the cells, suggesting that toxin form change is a biological defense reaction. Formation of pellicle cysts provides some protection against digestion, and dinoflagellates that survive passage through bivalves do so through the formation of pellicle cysts.

Acknowledgements. We thank an anonymous reviewer and P. G. Beninger for helpful comments. This experiment was performed with a travel grant from Längmanska kulturfonden and a research grant from Oscar and Lili Lamms Foundation for Scientific Research to A.P. Mention of trade names does not imply endorsement. 


\section{LITERATURE CITED}

Anderson DM, Kulis DM, Sullivan JJ, Hall S, Lee C (1990) Dynamics and physiology of saxitoxin production by the dinoflagellates Alexandrium spp. Mar Biol 104:511-524

Anderson DM, Glibert PM, Burkholder JM (2002) Harmful algal blooms and eutrophication: nutrient sources, composition, and consequences. Estuaries 25:704-726

Asakawa M, Miyazawa K, Takayama H, Noguchi T (1995) Dinoflagellate Alexandrium tamarense as the source of paralytic shellfish poison (PSP) contained in bivalves from Hiroshima Bay, Hiroshima Prefecture, Japan. Toxicon 33: 691-697

- Asakawa M, Beppu R, Ito K, Tsubota M, Takayama H, Miyazawa K (2006) Accumulation of paralytic shellfish poison (PSP) and biotransformation of its components in oysters, Crassostrea gigas, fed with the toxic dinoflagellate Alexandrium tamarense. Food Hyg Safety Sci 47: $28-32$

- Asp TN, Larsen S, Aune T (2004) Analysis of PSP toxins in Norwegian mussels by a post-column derivatization HPLC method. Toxicon 43:319-327

Bardouil M, Bohec M, Cormerais M, Bougrier S, Lassus P (1993) Experimental study of the effects of a toxic microalgal diet on feeding of the oyster Crassostrea gigas (Thunberg). J Shellfish Res 12:417-422

Bergkvist J, Selander E, Pavia H (2008) Induction of toxin production in dinoflagellates: the grazer makes a difference. Oecologia 156:147-154

Bricelj V, Shumway SE (1998) Paralytic shellfish toxins in bivalve molluscs: occurrence, transfer kinetics, and biotransformation. Rev Fish Sci 6:315-383

Cembella AD, Destombe C, Turgeon J (1990) Toxin composition of alternative life history stages of Alexandrium, as determined by high-performance liquid chromatography. In: Graneli E (ed) Toxic marine phytoplankton. Elsevier, Lund, p 333-338

Cembella AD, Shumway SE, Lewis NI (1993) Anatomical distribution and spatio-temporal variation in paralytic shellfish toxin composition in two bivalve species from the Gulf of Maine. J Shellfish Res 12:389-403

Cembella AD, Shumway SE, Larocque R (1994) Sequestering and putative biotransformation of paralytic shellfish toxins by the sea scallop Placopecten magellanicus: seasonal and spatial scales in natural populations. J Exp Mar Biol Ecol 180:1-22

Ciminiello P, Fattorusso E, Forino M, Montresor M (2000) Saxitoxin and neosaxitoxin as toxic principles of Alexandrium andersoni (Dinophyceae) from the Gulf of Naples, Italy. Toxicon 38:1871-1877

Etheridge SM, Pitcher GC, Roesler CS (2004) Depuration and transformation of PSP toxins in the South African abalone Haliotis midae. In: Steidinger KA, Landsberg JH, Thomas CR, Vargo GA (eds) Harmful algae 2002. Florida Fish and Wildlife Conservation Commission, Florida Institute of Oceanography, and Intergovernmental Oceanographic Commission of UNESCO, p 175-177

Falconer IR, Runnegar MTC, Buckley T, Huyn VL, Bradshaw $P$ (1989) Using activated carbon to remove toxicity from drinking water containing cyanobacterial blooms. J Am Water Works Assoc 81:102-105

Filho Ada S, da Costa SM, Ribeiro MG, Azevedo SM (2008) Effects of a saxitoxin-producer strain of Cylindrospermopsis raciborskii (Cyanobacteria) on the swimming movements of cladocerans. Environ Toxicol 23:161-168

- Flynn KJ, Flynn K, John EH, Reguera B, Reyero M, Franco JM (1996) Changes in toxins, intracellular and dissolved free amino acids of the toxic dinoflagellate Gymnodinium catenatum in response to changes in inorganic nutrients and salinity. J Plankton Res 18:2093-2111

Fux E, Marcaillou C, Mondeguer F, Bire R, Hess P (2008) Field and mesocosm trials on passive sampling for the study of adsorption and desorption behaviour of lipophilic toxins with a focus on OA and DTX1. Harmful Algae 7:574-583

Fux E, Bire R, Hess P (2009) Comparative accumulation and composition of lipophilic marine biotoxins in passive samplers and in mussels (M. edulis) on the West Coast of Ireland. Harmful Algae 8:523-537

Garcés E (2001) Temporary cysts in dinoflagellates. In: Garcés E, Zingone A, Montresor M, Reguera B, Dale B (eds) LIFEHAB: Life histories of microalgal species causing harmful blooms. European Commision, Calvià, p 46-48

Garcés E, Masó M, Camp J (2002) Role of temporary cysts in the population dynamics of Alexandrium taylori (Dinophyceae). J Plankton Res 24:681-686

Hamasaki K, Hoire M, Tokimitsu S, Toda T, Taguchi S (2001) Variability in toxicity of the dinoflagellate Alexandrium tamarense isolated from Hiroshima Bay, western Japan, as a reflection of changing environmental conditions. J Plankton Res 23:271-278

Hégaret H, Wikfors GH, Shumway SE (2007) Diverse feeding responses of five species of bivalve mollusc when exposed to three species of harmful algae. J Shellfish Res 26: $549-559$

Hégaret H, Shumway SE, Wikfors GH, Pate S, Burkholder JM (2008) Potential transport of harmful algae via relocation of bivalve molluscs. Mar Ecol Prog Ser 361:169-179

Hwang PA, Noguchi T, Hwang DF (2007) Paralytic shellfish poison as an attractant for toxic snails. Fish Sci 73:202-207

Ichimi K, Suzuki T, Yamasaki M (2001) Non-selective retention of PSP toxins by the mussel Mytilus galloprovincialis fed with the toxic dinoflagellate Alexandrium tamarense. Toxicon 39:1917-1921

Jaime E, Gerdts G, Luckas B (2007) In vitro transformation of PSP toxins by different shellfish tissues. Harmful Algae 6:308-316

Kayal N, Newcombe G, Ho L (2008) Investigating the fate of saxitoxins in biologically active water treatment plant filters. Environ Toxicol 23:751-755

Kim CJ, Kim CH, Sako Y (2005) Paralytic shellfish poisoning toxin analysis of the genus Alexandrium (Dinophyceae) occurring in Korean coastal waters. Fish Sci 71:1-11

Laabir M, Gentien P (1999) Survival of toxic dinoflagellates after gut passage in the Pacific oyster Crassostrea gigas Thunberg. J Shellfish Res 18:217-222

Laabir M, Amzil Z, Lassus P, Masseret E, Tapilatu Y, De Vargas R, Grzebyk D (2007) Viability, growth and toxicity of Alexandrium catenella and Alexandrium minutum (Dinophyceae) following ingestion and gut passage in the oyster Crassostrea gigas. Aquat Living Resour 20:51-57

- Lefebvre KA, Bill BD, Erickson A, Baugh KA and others (2008) Characterization of intracellular and extracellular saxitoxin levels in both field and cultured Alexandrium spp. samples from Sequim Bay, Washington. Mar Drugs 6: 103-116

Li AMY (2004) Uptake kinetics and biotransformation of paralytic shellfish poisoning toxins in Perna viridis. $\mathrm{PhD}$ thesis, City University of Hong Kong, p 118

MacKenzie L, White D, Oshima Y, Kapa J (1996) The resting cyst and toxicity of Alexandrium ostenfeldii (Dinophyceae) in New Zealand. Phycologia 35:148-155

MacKenzie L, Beuzenberg V, Holland P, McNabb P, Selwood A (2004) Solid phase adsorption toxin tracking (SPATT): a new monitoring tool that simulates the biotoxin contami- 
nation of filter feeding bivalves. Toxicon 44:901-918

Newcombe G, Nicholson B (2002) Treatment options for the saxitoxin class of cyanotoxins. Water Sci Technol 2: $271-275$

Newcombe G, Nicholson B (2004) Water treatment options for dissolved cyanotoxins. J Water Supply 53:227-239

Orr PT, Jones GJ, Hamilton GR (2004) Removal of saxitoxins from drinking water by granular activated carbon, ozone and hydrogen peroxide-implications for compliance with the Australian drinking water guidelines. Water Res 38:4455-4461

Oshima Y (1995) Post-column derivatization HPLC methods for paralytic shellfish poisons. In: Hallegraeff $G$, Anderson DM, Cembella A (eds) Manual of harmful marine microalgae. UNESCO, Paris, p 81-94

Parker NS, Negri AP, Frampton DMF, Rodolfi L, Tredici MR, Blackburn SI (2002) Growth of the toxic dinoflagellate Alexandrium minutum (Dinophyceae) using high biomass culture systems. J Appl Phycol 14:313-324

Persson A, Smith BC, Wikfors GH, Quilliam M (2006) Grazing on toxic Alexandrium fundyense resting cysts and vegetative cells by the eastern oyster (Crassostrea virginica). Harmful Algae 5:678-684

Rausch de Traubenberg C, Morlaix M (1995) Evidence of okadaic acid release into extracellular medium in cultures of Prorocentrum lima (Ehrenberg) Dodge. In: Lassus P, Arzul G, Erard E, Gentien P, Marcaillou C (eds) Harmful marine algal blooms. Lavoisier, Paris, p 493-498

Ravn H, Schmidt CU, Sten H, Anthoni U, Christophersen C, Nielsen PH (1995) Elicitation of Alexandrium ostenfeldii (Dinophyceae) affects the toxin profile. Comp Biochem Physiol C 111:405-412

Schantz EJ (1960) Biochemical studies on paralytic shellfish poisons. Ann NY Acad Sci 89:843-855

Sekiguchi K, Sato S, Ogata T, Kaga S, Kodama M (2001) Accumulation and depuration kinetics of paralytic shellfish toxins in the scallop Patinopecten yessoensis fed Alexandrium tamarense. Mar Ecol Prog Ser 220:213-218

Selander E, Thor P, Toth G, Pavia H (2006) Copepods induce paralytic shellfish toxin production in marine dinoflagellates. Proc Biol Sci 273:1673-1680

Shumway SE, Barter J, Sherman-Caswell S (1990) Auditing the impact of toxic algal blooms on oysters. Environ Audit

Editorial responsibility: Hans Heinrich Janssen, Oldendorf/Luhe, Germany
2:41-56

Shumway SE, Sherman SA, Cembella AD, Selvin R (1994) Accumulation of paralytic shellfish toxins by surfclams, Spisula solidissima (Dillwyn, 1897) in the Gulf of Maine: seasonal changes, distribution between tissues, and notes on feeding habits. Nat Toxins 2:236-251

Suzuki T, Ichimi K, Oshima Y, Kamiyama T (2003) Paralytic shellfish poisoning (PSP) toxin profiles and short-term detoxification kinetics in mussels Mytilus galloprovincialis fed with the toxic dinoflagellate Alexandrium tamarense. Harmful Algae 2:201-206

Taroncher-Oldenburg G, Kulis DM, Anderson DM (1999) Coupling of saxitoxin biosynthesis to the G1 phase of the cell cycle in the dinoflagellate Alexandrium fundyense: temperature and nutrient effects. Nat Toxins 7:207-219

- Teegarden GJ, Cembella AD, Capuano CL, Barron SH, Durbin EG (2003) Phycotoxin accumulation in zooplankton feeding on Alexandrium fundyense - vector or sink? J Plankton Res 25:429-443

Tillmann U, John U, Cembella A (2007) On the allelochemical potency of the marine dinoflagellate Alexandrium ostenfeldii against heterotrophic and autotrophic protists. J Plankton Res 29:527-543

Toth GB, Norén F, Selander E, Pavia H (2004) Marine dinoflagellates show induced life history shifts to escape parasite infection in response to water-borne signals. Proc Biol Sci 271:733-738

Twarog BM, Hidaka T, Yamaguchi H (1972) Resistance to tetrodotoxin and saxitoxin in nerves of bivalve mollusks. A possible correlation with paralytic shellfish poisoning. Toxicon 10:273-278

- Wang DZ (2008) Neurotoxins from marine dinoflagellates: a brief review. Mar Drugs 6:349-371

> Wang DZ, Ho AYT, Hsieh DPH (2002) Production of C2 toxin by Alexandrium tamarense CI01 using different culture methods. J Appl Phycol 14:461-468

Wiese M, D'Agostino PM, Mihali TK, Moffitt MC, Neilan BA (2010) Neurotoxic alkaloids: saxitoxin and its analogs. Mar Drugs 8:2185-2211

Wildish D, Lassus P, Martin J, Saulnier A, Bardouil M (1998) Effect of the PSP-causing dinoflagellate, Alexandrium sp. on the initial feeding response of Crassostrea gigas. Aquat Living Resour 11:35-43

Submitted: October 25, 2010; Accepted: June 17, 2011

Proofs received from author(s): August 30, 2011 